\title{
Traumatic injury in elderly: outcomes in emergency care unit
}

\author{
F Fama*, LM Murabito, SA Villari, CC Bramanti, MA Gioffrè Florio \\ From de Senectute: Age and Health Forum \\ Catanzaro, Italy. 5-7 December 2009
}

\section{Background}

In Italy, trauma has high incidence of accesses in emergency room (ER) and a significant number of affects elderly patients. Postural instability, poor visual function, functional limitation and comorbidity increase the risk of falls.

\section{Materials and methods}

Between 2007 to 2008, 1611 elderly patients were admitted in our ER for traumatic injuries with moderate to severe prognosis. In our department there are an area of trauma with two Shock Rooms, where the Trauma Team evaluates clinical status and vital parameters using a "Trauma Complex table". Survival probability (Ps) is evaluated by Triss (Trauma and Injury Severity Score) or by ISS (Injury Severity Score) methods.

\section{Results}

The most prevalent injuries were: 864 (53.63\%) head/ facial trauma, 83 (5.15\%), thoracic/ abdomen trauma. In over $50 \%$ of cases have involved single or multiple fractures, associated with major or minor trauma.

The incidence of femoral fractures was $16.69 \%$ (269 cases), followed by upper limbs $12.78 \%$ (206 cases) and ribs fractures $9.37 \%$ (151 cases).

The incidence of trauma in elderly population remained constant in the two years considered; the highest incidence interests the population with age range 75-84 years old. The majority of the patients was females(65.23\%).We have not observed any death in the emergency room.

613 patients (38.05\%) were hospitalized, 84 (5.21\%) has been transferred in other hospitals.

The $38.05 \%$ (613) of patients were discharged.

Dvision of Emergency Care Unit, University of Messina, Italy

\section{Conclusions}

The extension of the middle life increases the risk of home or walking traumatic injuries and the numbers of admission in ER. A correct management of trauma can reduce morbidity, mortality and hospitalization. The correct application of guide lines in Shock Room and the use of Trauma Complex table have allowed us to obtain an absence of mortality in ER. The prevalence of fractures in females, in our view, is related to osteoporosis.Particular attention should be carry out to patients undertaken anticoagulant therapy, because high morbidity was been observed later traumatic events.

\section{Published: 19 May 2010}

\section{References}

1. Gioffrè Florio M, Fama F, Gullo G, Buccheri G, Beccaria A, Caruso A, Cucinotta F, Estollo C, Malara C, Mamo M, Manti L, Placanica P, Versace G: The management of polytrauma: our experience. Chir Ital 2005, 57(4):485-9.

2. Raum MR, Nijsten MW, Vogelzang M, Schuring F, Lefering R, Bouillon B, Rixen D, Neugebauer EA, Ten Duis HJ: Emergency trauma score: An instrument for early aestimation of trauma severity. Crit Care Med 2009, 37(6):2122-3.

doi:10.1186/1471-2318-10-S1-A106

Cite this article as: Fama et al:. Traumatic injury in elderly: outcomes in emergency care unit. BMC Geriatrics 2010 10(Suppl 1):A106.

Submit your next manuscript to BioMed Central and take full advantage of:

- Convenient online submission

- Thorough peer review

- No space constraints or color figure charges

- Immediate publication on acceptance

- Inclusion in PubIMed, CAS, Scopus and Google Scholar

- Research which is freely available for redistribution 